\title{
Jurist-Diction
}

Volume 2 No. 5, September 2019

Histori artikel: Submit 04 Agustus 2019; Diterima 19 Agustus 2019; Diterbitkan online 1 September 2019.

\section{Kepastian Hukum Dalam Perizinan Berusaha Terintegrasi Secara Elektronik (Online Single Submission) di Indonesia}

\author{
Desi Arianing Arrum \\ desi.arianing.arrum-2015@fh.unair.ac.id \\ Universitas Airlangga
}

\begin{abstract}
In order to facilitate the investment climate in Indonesia, Government Regulation Number 24 of 2018 about Electronic Integrated Business Licensing Services (OSS) aims to support the increase in the index of ease of doing business. This research is a legal dogmatic research. The approach method used is a legislative approach and a conceptual approach to review existing legal issues. The data source of this writing comes from library research on books, papers, journals relating to administrative law and licensing law. Through this writing the author discusses the concept of legal certainty in OSS along with the problems after the enactment of the government regulation. OSS is basically intended to make it easier for businesses to get legality. Before the entry into force of the OSS, the license applicant was required to fulfill the requirements first to obtain a business license, but after the entry into force of the OSS the businessman who registered on the OSS page obtained a business license and then fulfilled the commitment. Against the failure of business actors to fulfill commitments resulting in business activities cannot be operational. Business licenses that have been issued can be canceled when the business actor does not meet the commitments within the specified time limit. Legal uncertainty arises over business licenses that have been issued by the government even though business licenses are a form of State Administrative Decision. The legitimate expectation carried out by the government over the issuance of business licenses that have not yet been finalized has the potential to harm business actors. The ease of licensing is indeed needed to encourage the improvement of the investment climate in Indonesia without forgetting the principle of permission as a controlling instrument for the community that is realized through supervision in the region.
\end{abstract} Keywords: Legal Certainty; Online Single Submission; Legitimate Expectation.

\begin{abstract}
Abstrak
Dalam rangka memudahkan iklim investasi di Indonesia, Peraturan Pemerintah Nomor 24 Tahun 2018 Tentang Pelayanan Perizinan Berusaha Terintegrasi Secara Elektronik (OSS) bertujuan menunjang kenaikan indeks ease of doing business. Penelitian ini merupakan penelitian dogmatika hukum. Metode pendekatan yang digunakan adalah pendekatan perundang-undangan dan pendekatan konseptual untuk mengkaji permasalahan hukum yang ada. Sumber data dari penulisan ini berasal dari riset kepustakaan terhadap bukubuku, makalah, jurnal yang berkaitan dengan hukum administrasi dan hukum perizinan. Melalui penulisan ini penulis membahas konsep kepastian hukum dalam OSS beserta problematika pasca berlakunya peraturan pemerintah tersebut. OSS pada dasarnya dimaksudkan untuk mempermudah pelaku usaha mendapatkan legalitas. Sebelum berlakunya OSS pemohon izin diwajibkan memenuhi syarat-syarat terlebih dahulu baru mendapatkan izin usaha, namun pasca berlakunya OSS pelaku usaha yang mendaftar pada laman OSS memperoleh izin usaha kemudian memenuhi komitmen. Terhadap gagalnya para pelaku usaha memenuhi komitmen berakibat kegiatan usaha tidak dapat beroperasional. Izin usaha yang sudah diterbitkan dapat dibatalkan ketika pelaku usaha tidak kunjung memenuhi komitmen dalam batas waktu yang telah ditentukan. Muncul ketidakpastian hukum atas izin usaha yang sudah diterbitkan pemerintah padahal izin usaha merupakan salah satu bentuk Keputusan Tata Usaha Negara. Legitimate expectation yang dilakukan pemerintah atas terbitnya izin usaha yang belum final berpotensi merugikan pelaku usaha. Kemudahan perizinan memang diperlukan untuk semangat meningkatkan iklim investasi di Indonesia tanapa melupakan prinsip izin sebagai instrumen pengendali masyarakat yang diwujudkan melalui pengawasan di daerah.
\end{abstract}

Kata Kunci: Kepastian Hukum; Online Single Submission; Legitimate Expectation. 


\section{Pendahuluan}

Perizinan adalah salah satu bentuk pelaksanaan fungsi pengaturan dan bersifat pengendalian yang dimiliki oleh pemerintah terhadap kegiatan-kegiatan yang dilakukan oleh masyarakat. Perizinan dapat berbentuk pendaftaran, rekomendasi, sertifikasi, penentuan kuota, dan izin untuk melakukan suatu usaha yang biasanya harus dimiliki atau diperoleh suatu organisasi perusahaan atau seseorang sebelum yang bersangkutan dapat melakukan suatu kegiatan atau tindakan. ${ }^{1}$ Merujuk pandangan M. Hadjon dalam bukunya yang berjudul Pengantar Hukum Administrasi, perizinan sebagai salah satu keputusan dalam rangka ketentuan-ketentuan larangan dan atau ketentuan-ketentuan perintah. Larangan ini tidak dimaksudkan secara mutlak namun untuk dapat bertindak dan mengendalikan masyarakat dengan cara mengeluarkan izin, khususnya dengan menghubungkan peraturan-peraturan pada izin itu. ${ }^{2}$ Berdasarkan ketentuan Pasal 28J ayat (1) Undang-Undang Dasar Negara Republik Indonesia Tahun 1945 bahwa setiap orang wajib menghormati hak asasi manusia orang lain dalam tertib kehidupan bermasyarakat, berbangsa, dan bernegara sehingga penerbitan izin dimaksudkan untuk menata kegiatan dalam masyarakat agar tidak mengurangi hak masyarakat yang lain guna menjadikan penyelenggaraan negara yang tertib bermasyarakat, berbangsa, dan bernegara. Izin merupakan salah satu instrumen yang diperlukan pemerintah untuk mengendalikan atau membatasi hak seseorang untuk mencapai ketertiban.

Dalam negara kesataun, pemerintah daerah sesuai Pasal 18 ayat (1) UndangUndang Dasar Negara Republik Indonesia dibagi atas daerah-daerah provinsi dan daerah provinsi itu dibagai atas kabupaten dan kota yang tiap-tiap provinsi, kabupaten dan kota mempunyai pemerintahan daerah yang diatur dengan undangundang. Urusan Pemerintahan adalah kekuasaan pemerintahan yang menjadi kewenangan Presiden yang pelaksanaannya dilakukan oleh kementerian negara dan penyelenggara Pemerintahan Daerah untuk melindungi, melayani, memberdayakan,

\footnotetext{
1 Adrian Sutedi, Hukum Perizinan Dalam Sektor Pelayanan Publik (Sinar Grafika 2017).[168].

${ }^{2}$ Philipus M. Hadjon, et.al, Pengantar Hukum Administrasi Indonesia (Gadjah Mada University Press 2002).[126].
} 
dan menyejahterakan masyarakat. Kemudian pada Pasal 18 ayat (2) UndangUndang Dasar Negara Republik Indonesia, pemerintah daerah mempunyai wewenang otonomi dan tugas pembantuan, salah satunya adalah mengeluarkan izin sebagaimana tercantum dalam Undang-Undang Republik Indonesia Nomor 23 Tahun 2014 tentang Pemerintahan Daerah (selanjutnya disebut UU 23/2014). Kewenangan yang diberikan bukan kewenangan utuh tetapi masih memperhatikan pemerintah pusat sehingga tetap harus memperhatikan koordinasi dari pemerintah pusat sebagaimana ketentuan pembagian urusan pemerintahan dalam UU 23/2014.

Berdasarkan ketentuan Pasal 10 UU 23/2014 pembagian urusan pemerintahan terdiri atas urusan pemerintahan absolut, urusan pemerintahan konkuren, dan urusan pemerintahan umum. Kewenangan mengurus perizinan termasuk dalam urusan pemerintahan konkuren sehingga dalam pelaksanaannya sangat erat kaitannya antara peemrintah pusat dengan pemerintah daerah. Saat ini pemerintahan di seluruh dunia khususnya di Indonesia tengah menghadapi tekanan dari berbagai pihak untuk meningkatkan kualitas pelayanan publik dan meningkatkan partisipasi aktif dalam pemberian informasi bagi masyarakat serta dituntut untuk lebih efektif. ${ }^{3}$ Hal tersebutlah yang kemudian mendorong pemerintahan berbasis elektronik semakin diterapkan disemua jenjang administrasi publik tidak terkecuali dalam lingkup perizinan.

Melalui Peraturan Pemerintah Nomor 24 Tahun 2018 tentang Pelayanan Perizinan Berusaha Terintegrasi Secara Elektronik (selanjutnya disebut PP 24/2018), Presiden Joko Widodo selaku kepala pemerintahan tertinggi memaksa pemerintah daerah untuk segera menyelenggarakan perizinan berusaha terintegrasi secara elektronik atau online single submission (OSS). ${ }^{4}$ Hal tersebut dimaksudkan untuk mengejar ketertinggalan Indonesia dalam kemudahan layanan perizinan

\footnotetext{
3 Erick S. Holle, 'Pelayanan Publik Melalui Electronic Government : Upaya meminimalisir Praktek Maladministrasi dalam Meningkatkan Public Service’, (2011) 17 Jurnal Sasi.[21].

4 Arya Aditya, 'Sistem Perizinan Online Tunggal, Jokowi : Kita Paksa' (cnbcindonesia.com, 2018) <https://www.cnbcindonesia.com/news/20180418171510-4-11538/sistem-perizinan-online-tunggal-jokowi-kita-paksa $>$ accessed 18 September 2018.
} 
dari negara-negara tetangga seperti Vietnam, Malaysia dan Singapura. ${ }^{5}$ Sehingga dalam rangka percepatan dan peningkatan penanaman modal dan berusaha dibentuklah OSS.

Pasca berlakunya OSS dalam rangka menunjang ease of doing business (EODB) ternyata berkorelasi secara signifikan dalam menaikkan peringkat kemudahan perizinan di Indonesia. Berdasarkan data yang dilansir Bank Dunia dengan berlakunya OSS indicator starting a business naik 10 peringkat dari 144 menjadi 134. Sekalipun peringkat EODB Indonesia dalam laporan Doing Business 2019 turun dari peringkat 72 menjadi peringkat 73, namun indeks EODB Indonesia naik 1,42 menjadi 67,96 dibandingkan tahun sebelumnya. ${ }^{6}$

Pada negara hukum modern tugas dan kewenangan pemerintah nyatanya tidak sekedar menjaga ketertiban dan keamanan (rust en orde), namun juga mengupayakan kesejahteraan umum (bestuurszorg). Dalam rangka merealisasikan tugas dan kewenangan pemerintah tersebut hukum memberikan wewenang dalam bidang pengaturan kepada pemerintah. Berdasarkan fungsi pengaturan ini munculah instrumen yuridis dalam rangka menghadapi peristiwa individual dan konkret yaitu dalam bentuk ketetapan. Salah satu wujud dari ketetapan ini adalah izin.

Izin (vergunning) berdasarkan konsep dalam Undang-Undang Republik Indonesia Nomor 30 Tahun 2014 tentang Administrasi Pemerintahan (selanjutnya disebut UU 30/2014) ialah keputusan pejabat pemerintahan yang berwenang sebagai wujud persetujuan atas permohonan warga masyarakat sesuai dengan ketentuan peraturan perundang-undangan. Izin dimaksudkan oleh keinginan pembuat undang-undang untuk mencapai suatu tatanan tertentu atau untuk menghalangi keadaan-keadaan yang buruk. Tujuannya ialah mengatur tindakantindakan yang oleh pembuat undang-undang tidak seluruhnya dianggap tercela,

\footnotetext{
5 Agung Pambudhy, 'Kemudahan Usaha RI Kalah dari Vietnam Hingga Singapura' (m.detik. com, 2019) https://m.detik.com/finance/berita-ekonomi-bisnis/d-4283004/kemudahan-usaha-rikalah-dari-vietnam-hingga-singapura accessed 21 Januari 2019.

${ }^{6}$ Prima Wirayani, 'Ease od Doing Business RI Turun, Ini Penjelasan Bank Dunia', (cnbcindonesia.com, 2018) <http:/www.cnbcindonesia,com/news/20181031201049-4-40020/easeof-doing-business-ri-turun-ini-penjelasan-bank-dunia> accessed 20 April 2018.
} 
namun menginginkan dapat melakukan pengawasan sekedarnya. Dalam arti sempit konsep perizinan ialah bahwa tindakan dilarang, terkecuali diperkenankan dengan tujuan agar dalam ketentuan-ketentuan yang disangkutkan dengan perkenan dapat dengan teliti diberikan batas-batas tertentu bagi tiap kasus. ${ }^{7}$

Sehingga izin digunakan oleh penguasa sebagai instrument untuk mempengaruhi (hubungan dengan) para warga agar mau mengikuti cara yang dianjurkan guna mencapai suatu tujuan konkret. Perizinan berusaha yang diterbitkan oleh kementerian/lembaga dan pemerintah daerah untuk memulai, melaksanakan, dan mengembangkan kegiatan usaha, perlu ditata kembali agar menjadi pendukung dan bukan sebaliknya menjadi hambatan perkembangan kegiatan usaha. Dengan diundangkannya PP 24/2018 tentunya mengubah secara mendasar sistem penerbitan izin di Indonesia. OSS dimaksudkan untuk mempermudah pelaku usaha mendapatkan legalitas. Pemangkasan prosedur yang lama dimana pada mulanya pemohon izin memenuhi syarat-syarat terlebih dahulu barulah mendapatkan izin usaha kini melalui OSS para pelaku usaha diberikan kemudahan informasi dan kejelasan prosedur dalam berbagai tahap sebagaimana dapat diakses melalui laman url: http://oss.go.id.

Secara teknis OSS merupakan aplikasi berbasis web yang berfungsi untuk membantu proses pengajuan pengaduan dan perizinan untuk selajutnya dilakukan proses penindakan yang dilakukan oleh peran pengambil keputusan, aplikasi web OSS (Online Single Submission) ini menyediakan informasi seperti data permohonan berusaha, data perizinan yang ada, data instansi daerah, data perizinan daerah, dan lain-lain. ${ }^{8}$ Adapun Pasal 1 angka 5 PP 24/2018 mendefinisikan OSS sebagai perizinan berusaha yang diterbitkan oleh Lembaga OSS untuk dan atas nama menteri, pimpinan lembaga, gubernur, atau bupati/wali kota kepada pelaku usaha melalui sistem elektronik yang terintegrasi.

\footnotetext{
7 Philipus M. Hadjon. ed, Pengantar Hukum Perizinan (Yuridika 1993).[3].

8 Kementerian Koordinator Bidang Perekonomian Republik Indonesia, Online Single Submission (Panduan Penggunaan Registrasi OSS version 1.00 Kementerian Koordinator Bidang Perekonomian Republik Indonesia 2018).[7].
} 
OSS membawa terobosan automatic approval yang menyeragamkan persyaratan dan tidak perlu adanya proses review dokumen sepanjang memenuhi persyaratan administrasi dalam portal maka akan langsung mendapatkan izin usaha. Perbedaan mendasar antara OSS dengan sistem perizinan sebelumnya ialah bahwa pada mulanya dalam sistem perizinan pemohon izin memenuhi syarat-syarat terlebih dahulu barulah mendapatkan izin usaha kini melalui OSS pemohon izin mendapatkan izin usaha terlebih dahulu barulah melengkapi syarat-syarat.

Catatan penting dalam penerbitan perizinan berusaha bahwa meskipun izin usaha sudah diterbitkan para pelaku usaha tidak berarti bisa langsung beroperasi. Pelaku usaha harus memperoleh izin operasional dan/atau izin komersial terlebih dahulu sebagai syarat-syarat sebagaimana ketentuan Pasal 41 PP 24/2018. Tentunya hal ini membawa ketidakpastian hukum bagi pelaku usaha yang sudah mendapatkan izin berusaha namun ternyata belum bisa melaksanakan kegiatan usaha.

Berdasarkan ketentuan Pasal 1 angka 9 Undang-Undang Republik Indonesia Nomor 5 Tahun 1986 tentang Peradilan Tata Usaha Negara yang telah diubah dua kali melalui Undang-Undang Republik Indonesia Nomor 9 Tahun 2004 dan UndangUndang Republik Indoensia Nomor 51 Tahun 2009 (selanjutnya disebut UU PTUN) konsep dasar dari KTUN ialah penetapan tertulis yang dikeluarkan oleh pejabat tata usaha negara yang bersifat konkret, individual dan final, yang menimbulkan akibat hukum bagi seseorang atau badan hukum perdata. Meskipun izin usaha diakui sebagai KTUN namun pada praktiknya izin usaha tidak bersifat final. Padahal sifat keputusan perizinan sebagiamana pandangan Philipus M. Hadjon dalam bukunya yang berjudul Pengantar Hukum Perizinan berdasarkan akibat hukumnya izin dipaparkan sebagai keputusan yang menciptakan hukum, dengan pemberian izin timbul hubungan hukum tertentu. ${ }^{9}$ Begitu pula pandangan Adrian Sutedi yang mengelompokkan izin sebagai ketetapan yang bersifat konstitutif yakni ketetapan yang menimbulkan hak baru yang sebelumnya tidak dimiliki oleh seseorang yang namanya tercantum dalam ketetapan itu (beschikkingen welke iets toestaan wat tevoren niet geoorloofd was). ${ }^{10}$

\footnotetext{
9 Philipus M. Hadjon I, Op.Cit.,[7].

${ }^{10}$ Adrian Sutedi, Op.Cit.,[180].
} 
Berdasarkan ketentuan dalam Pasal 1 angka 5 jo. Pasal 19 ayat (2) PP 24/2018 perizinan yang dikeluarkan oleh lembaga OSS ialah untuk dan atas nama menteri, pimpinan, lembaga, gubernur, atau bupati/wali kota kepada pelaku usaha melalui sistem elektronik yang terintegrasi. Dengan adanya frasa untuk dan atas nama maka kewenangan dari lembaga OSS tersebut berupa mandat yang berdasarkan ketentuan Pasal 1 angka 24 UU 30/2014 berarti pelimpahan kewenangan dari badan dan/atau pejabat pemerintahan yang lebih tinggi kepada badan dan/atau pejabat pemerintahan yang lebih rendah dengan tanggung jawab dan tanggung gugat tetap pada pemberi mandate. Kewenangan yang bersifat mandat tersebut berarti tanggung jawab dan tanggung gugat tetap berada pada pemerintah daerah (pemberi mandat) namun dalam OSS pemerintah daerah tidak dapat dengan leluasa mengontrol penerbitan perizinan tanpa komitmen seperti izin usaha perdagangan yang merupakan izin usaha sekaligus merupakan izin komersial atau operasional untuk kegiatan perdagangan.

Konsep dari mandat adalah dari pejabat yang lebih tinggi kepada pejabat yang lebih rendah, namun dalam OSS justru kewenangan pejabat daerah di mandatkan oleh PP 24/2018 pada lembaga OSS (lembaga pemerintah non kementerian yang menyelenggarakan urusan pemerintahan di bidang koordinasi penanaman modal). Saat ini tidak diatur secara jelas hubungan struktural seperti apa antara pejabat daerah dengan lembaga OSS. Ketidakjelasan struktural dalam hubungan kerja menyebabkan kerancuan dalam penerapan konsep mandat. Apabila kewenangan secara mandat tersebut terdapat kecacatan kewenangan maka berakibat batal demi hukum.

Salah satu prinsip rechsstaat menurut Julius Sthal ialah pemerintahan berdasarkan peaturan-peraturan (wetmatigheid van bestuur). ${ }^{11}$ Sehingga setiap tindakan pemerintah baik dalam menjalankan fungsi pengaturan maupun fungsi pelayanan harus berdasarkan wewenang yang diberikan oleh peraturan perundangundangan yang berlaku. Mengutip pendapat F.A.M Stroink en J.G. Steenbeek yang dikutip oleh Adrian Sutedi bahwa om positief recht ten kunnen vasstellen en

${ }^{11}$ H. A. Masyhur Effendi, Hak Asasi Manusia Dalam Hukum Nasional dan Internasional (Ghalia Indonesia 1993).[32]. 
handhaven is een bevoegdheid noodzakelijk. Zonder bevoegdheid kunnen geen juridisch concrete besluiten genomen worden. Yang memiliki makna bahwa untuk dapat melaksanakan dan menegakkan ketentuan hukum positif diperlukan suatu wewenang. Tanpa wewenang tidak dapat dibuat keputusan yuridis yang bersifat konkret, maka keabsahan kewenangan dalam penerbitan izin merupakan hal yang vital dalam penyelenggaraan negara hukum. ${ }^{12}$

Berdasarkan konsep pembagian porsi urusan pemerintah pusat dan daerah ketentuan Pasal 12 ayat (3) UU 23/2014 menyebutkan perdagangan dan perindustrian sebagai salah satu bentuk urusan pemerintahan konkuren yang berupa urusan pemerintahan pilihan. Dengan adanya OSS maka seakan-akan kewenangan penerbitan izin berusaha ditarik pada pemerintah pusat seluruhnya sedangkan dalam Pasal 13 UU 23/2014 pembagian urusan pemerintahan konkuren antara pemerintah pusat dan pemerintah daerah didasarkan pada prinsip akuntabilitas, efisiensi, dan eksternalitas serta kepentingan strategis nasional.

Berdasarkan lampiran DD UU 23/2014 pembagian urusan pemerintahan bidang perdagangan undang-undang tersebut telah membagi secara spesifik kewenangan perizinan dan pendaftaran periziann di bidang perdagangan antara pemerintah pusat, pemerintah daerah provinsi dan pemerintah daerah kabupaten/ kota begitu pula dengan lampiran EE tentang pembagian urusan pemerintahan bidang perindustrian. Melalui PP 24/2018 seakan pemerintah pusat mengambil seluruh kewenangan daerah melalui OSS dengan tetap melempar tanggungjawab dan tanggung gugat kepada pemerintah daerah. Sehingga keabsahan dari izin yang diterbitkan OSS patut dipertanyakan.

\section{Metode Penelitian}

Penelitian ini merupakan penelitian hukum nomatif (penelitian hukum doktrinal). Sebagaimana jenis penelitian normatif maka metode pendekatan yang digunakan dalam penelitian ini adalah pendekatan undang-undang (statute

\footnotetext{
${ }^{12}$ Adrian Sutedi, Op.Cit.,[179].
} 
approach) dan pendekatan konseptual (conceptual approach).${ }^{13}$ Sumber penelitian dapat dibedakan menjadi sumber hukum primer, sekunder, dan tersier. Pengumpulan bahan hukum dilakukan dengan cara studi kepustakaan (library research). ${ }^{14}$ Hasil analisa dari bahan hukum akan diinterpretasikan menggunakan metode interpretasi sistematis dan gramatikal. ${ }^{15}$

\section{Keabsahan Izin Usaha dalam Sistem Pelayanan Online Single Submission (OSS)}

Pelayanan publik sebagaimana Pasal 1 angka 1 Undang-Undang Nomor 25 Tahun 2009 tentang Pelayanan Publik (selanjutnya disebut UU 25/2009), yaitu suatu kegiatan atau rangkaian kegiatan dalam rangka pemenuhan kebutuhan pelayanan sesuai dengan peraturan perundang-undangan bagi setiap warga negara dan penduduk atas barang, jasa, dan atau pelayanan administrasi yang disediakan oleh penyelenggara pelayanan publik. Sementara itu Black's Law Dictionary mengartikan : "public service is a service provided or facilitied by government for the general public's convenience and benefit."

Salah satu bentuk pelayanan publik yang sangat mendasar dan menjadi tugas negara sekaligus sebagai upaya untuk mencapai tujuan negara adalah meningkatkan kesejahteraan rakyat sebagaimana tercantum dalam Pembukaan Undang-Undang Dasar Negara Tahun 1945. Ruang lingkup pelayanan publik meliputi pelayanan barang publik dan jasa publik serta pelayanan administratif yang diatur dalam peraturan perundang-undangan khususnya UU 2/2009. Berdasarkan ketentuan Pasal 5 ayat (7) UU 25/2009 pelayanan administratif meliputi:

a. tindakan administratif pemerintah yang diwajibkan oleh negara dan diatur dalam peraturan perundang-undangan dalam rangka mewujudkan perlindungan pribadi, keluarga, kehormatan, martabat, dan harta benda.

b. tindakan administratif oleh instansi nonpemerintah yang diwajibkan oleh negara

13 I Made Pasek Diantha, Metodologi Penelitian Hukum Normatif (Prenada Media Group 2016).[156].

14 Soerjono Soekanto dan Sri Mamudji, Penelitian Hukum Normatif (Rajagrafindo Persada 1985).[41].

15 ibid.[152]. 
dan diatur dalam peraturan perundang-undangan serta diterapkan berdasarkan perjanjian dengan penerima pelayanan.

Tindakan administratif pemerintah merupakan pelayanan pemberian dokumen oleh pemerintah, antara lain yang dimulai dari seseorang yang lahir memperoleh akta kelahiran hingga meninggal dan memperoleh akta kematian, termasuk segala hal ihwal yang diperlukan oleh penduduk dalam menjalani kehidupannya, seperti memperoleh izin mendirikan bangunan, izin usaha, sertifikat tanah, dan surat nikah.

Tindakan administratif nonpemerintah merupakan pelayanan pemberian dokumen oleh instansi di luar pemerintah, antara lain urusan perbankan, asuransi, kesehatan, keamanan, pengelolaan kawasan industri, dan pengelolaan kegiatan sosial.

Izin dalam lingkup pelayanan publik merupakan pelayanan administratif berupa tindakan administratif pemerintah yang diwajibkan oleh negara dan diatur dalam peraturan perundang-undangan dalam rangka mewujudkan perlindungan pribadi, keluarga, kehormatan, martabat, dan harta benda. Izin berdasarkan ketentuan Pasal 28J Undang-Undang Dasar Negara Republik Indonesia Tahun 1945 ialah dalam rangka pengendalian yang dimaksudkan untuk menata kegiatan dalam masyarakat agar tidak mengurangi hak orang lain. Bahwa setiap orang wajib menghormati hak asasi manusia orang lain dalam tertib kehidupan bermasyarakat, berbangsa, dan bernegara sehingga penerbitan izin dimaksudkan untuk menata kegiatan dalam masyarakat agar tidak mengurangi hak masyarakat yang lain guna menjadikan penyelenggaraan negara yang tertib bermasyarakat, berbangsa, dan bernegara. Izin merupakan salah satu instrumen yang diperlukan pemerintah untuk mengendalikan atau membatasi hak seseorang untuk mencapai ketertiban.

Dalam negara kesataun, pemerintah daerah sesuai Pasal 18 ayat (1) UndangUndang Dasar Negara Republik Indonesia dibagi atas daerah-daerah provinsi dan daerah provinsi itu dibagai atas kabupaten dan kota yang tiap-tiap provinsi, kabupaten dan kota mempunyai pemerintahan daerah yang diatur dengan undangundang. Urusan pemerintahan adalah kekuasaan pemerintahan yang menjadi kewenangan presiden yang pelaksanaannya dilakukan oleh kementerian negara dan 
penyelenggara pemerintahan daerah untuk melindungi, melayani, memberdayakan, dan menyejahterakan masyarakat.

Berdasarkan Pasal 18 ayat (2) Undang-Undang Dasar Negara Republik Indonesia, pemerintah daerah mempunyai wewenang otonomi dan tugas pembantuan, salah satunya adalah mengeluarkan izin sebagaimana tercantum dalam UU 23/2014. Kewenangan yang diberikan bukan kewenangan utuh tetapi kewenangan konkuren yang masih memperhatikan pemerintah pusat sehingga tetap harus memperhatikan koordinasi dari pemerintah pusat sebagaimana ketentuan pembagian urusan pemerintahan dalam UU 23/2014. Pemerintah pusat dan pemerintah daerah semakin memperbaiki sistem perizinan di Indoneisa baik melalui sistem pelayanan perizinan satu pintu, pelayanan perizinan terpadu satu atap hingga pasca berlakunya PP 24/2018 yaitu pelayanan perizinan melalui sistem Online Single Submission (OSS).

Terdapat berbagai macam izin dalam perizinan berusaha seperti izin usaha dan izin operasional (izin komersial). Berdasarkan Pasal 1 angka 8 PP 24/2018, yang dimaksud dengan Izin Usaha adalah izin yang diterbitkan oleh lembaga OSS untuk dan atas nama menteri, pimpinan lembaga, gubernur, atau bupati/wali kota setelah pelaku usaha melakukan pendaftaran dan untuk memulai usaha dan/atau kegiatan sampai sebelum pelaksanaan komersial atau operasional dengan memenuhi persyaratan dan/atau komitmen.

Izin sebagai salah satu tindakan pemerintahan yang menjadi sarana pengendalianterhadaptingkahlaku masyarakat, maka sebagaitindakanpemerintahan izin harus memenuhi asas keabsahan. Berdasarkan legitimasi tindakan pemerintah dalam menerbitkan izin, maka unsur keabsahan itu dapat dianalisa dengan 3 (tiga) hal, yaitu wewenang, substansi dan prosedur. Wewenang sebagai konsep inti dalam Hukum Administrasi Negara dan Hukum Tata Negara sebagai hukum publik yang sekurang-kurangnya terdiri atas 3 (tiga) komponen diantaranya adalah pengaruh, dasar hukum dan konformitas hukum. ${ }^{16}$ Komponen dasar hukum bermakna bahwa 
dalam setiap wewenang yang dimiliki oleh pejabat negara harus dapat ditunjuk dasar hukumnya sebagai realisasi dari asas legalitas.

Pada prinsipnya oleh karena izin merupakan pembatasan terhadap hak asasi manusia yang digunakan sebagai saran pengendalian maka setiap kewenangan untuk menetapkan izin harus diatur dalam peraturan perundang-undangan yang mendapat persetujuan dari wakil rakyat (berupa undang-undang ataupun peraturan daerah). Izin usaha dalam Sistem online single submission (OSS) mendapatkan legitimasi dari peraturan pemerintah yakni PP 24/2018, tentu hal tersebut telah melanggar komponen wewenang khususnya dasr hukum. Peraturan Pemerintah sebagai legitimasi OSS tidak dibuat berdasarkan persetujuan dari wakil rakyat. Wewenang lembaga OSS yang didapatkan melalui legitimasi Peraturan Pemerintah tidaklah sah karena melanggar komponen dasar hukum wewenang. Tidak sahnya wewenang dalam suatu izin berakibat izin tersebut batal demi hukum.

Kewenangan membuat keputusan (izin) hanya dapat diperoleh dengan cara atribusi, delegasi dan mandat. Mengutip pandangan Philipus M. Hadjon bahwa wewenang yang ada pada badan atau pejabat tata usaha negara yang dilawankan dengan wewenang yang dilimpahkan ${ }^{17}$ berdasarkan ketentuan Pasal 1 angka 22 UU 30/2014 bahwa yang dimaksud dengan atribusi adalah pemberian Kewenangan kepada Badan dan/atau Pejabat Pemerintahan oleh Undang-Undang Dasar Negara Republik Indonesia Tahun 1945 atau Undang-Undang. Contoh izin yang terbit dari kewenangan atribusi adalah wewenang menerbitkan izin lingkungan, amdal atau UKL-UPL berdasarkan ketentuan Undang-Undang Nomor 32 Tahun 2009 tentang Perlindungan dan Pengelolaan Lingkungan Hidup.

Delegasi berdasarkan ketentuan Pasal 1 angka 23 UU 30/2014 adalah pelimpahan Kewenangan dari Badan dan/atau Pejabat Pemerintahan yang lebih tinggi kepada Badan dan/atau Pejabat Pemerintahan yang lebih rendah dengan tanggung jawab dan tanggung gugat beralih sepenuhnya kepada penerima delegasi. Contoh izin yang berasal dari delegasi diantaranya: wewenang pemberian izin usaha

${ }^{17}$ Philipus M Hadjon, Op.Cit.[130]. 
dalam rangka penanaman modal kepada Kepala BP Batam, BP Bintan, dan BP Karimun berdasarkan ketentuan ABKPM Nomor. 9 tentang Pelimpahan Wewenang Pemberian Izin Usaha Dalam Rangka Penanaman Modal Kepada Kepala BP Batam, BP Bintan, dan BP Karimun; wewenang perizinan direktur Jendral Ketenagalistrikan dari Menteri ESDM dalam pemberian keputusan perizinan ketenagalistrikan sebagaimana Keputusan Menteri ESDM Kepada Direktur Jendral Ketenagalistrikan dalam Pemberian Keputusan Perizinan di bidang Ketenagalistrikan.

Mandat berdasarkan ketentuan Pasal 1 angka 24 UU 30/2014 adalah pelimpahan kewenangan dari badan dan/atau pejabat pemerintahan yang lebih tinggi kepada badan dan/atau pejabat pemerintahan yang lebih rendah dengan tanggung jawab dan tanggung gugat tetap berada pada pemberi mandat. Mandat sebagai suatu pelimpahan wewenang dimaksudkan untuk memberi wewenang kepada bawahan dalam membuat keputusan (izin) a.n pejabat tun yang memberi mandat, sehingga keputusan itu tetap merupakan keputusan pejabat tun yang memberi mandat. Terhadap keputusan tersebut tanggung jawab dan tanggung gugat tetap berada pada pemberi mandate. Meggutip pendapat Philipus M. Hadjon bahwa dalam keseharian mandate telah dialihkan menjadi delegasi semu. Contoh penerbitan izin dari mandat adalah izin mendirikan bangunan (IMB) yang merupakan wewenang Walikota dialihkan seakan-akan menjadi wewenang Kepala Dinas Cipta Karya dan Tata Ruang. Kepala Dinas Cipta Karya dan Tata Ruang tidka lagi membuat keputusan (izin) a.n Kepala Daerah tetapi membuat keputusan berdasarkan wewenang semu yang ada padanya. ${ }^{18}$

Berdasarkan ketentuan Pasal 1 angka 24 UU 30/2014 jo. Pasal 1 angka 8 PP 24/2018 bahwa izin usaha yang diterbitkan oleh lembaga OSS merupakan mandat dari pemerintah daerah padahal lazimnya mandat diberikan berdasarkan jabatan struktural dari atasan kepada bawahan. Meminjam istilah dari Philipus M Hadjon bahwa dapat dikatakan telah terjadi penyelundupan hukum dalam penggunaan mandat sebagai penerbitan izin menghindari gugatan terhadap lembaga OSS. 
Kewenangan yang dilimpahkan dari pemerintah daerah kepada lembaga OSS sejatinya belum jelas macam figure wewenang yang ada pada sistem online single submission (OSS) ini. Secara konseptual kewenangan penerbitan izin melalui sistem online single submission (0SS) ialah membingungkan padahal tidak sahnya wewenang dalam suatu izin berakibat izin tersebut batal demi hukum.

Negara Indonesia selaku negara kesatuan memiliki hubungan yang sangat erat antara pemerintah pusat dengan pemerintah daerah dalam rangka penyelenggaraan pemerintahan. Pemerintahan daerah provinsi, daerah kabupaten dan kota mengatur dan mengurus sendiri urusan pemerintahan menurut asas otonomi dan tugas pembantuan. Sehingga dalam peneribitan izin atas dasar asas penyelenggaraan daerah dapat merupakan kewenangan yang dimiliki pusat, daerah provinsi dan daerah kabupaten/kota sesuai pembagian kewenangan dalam UU 23/2014. Pada konsep penyelenggaraan daerah sebagaimana ketentuan UU 23/2014 pemberian izin dibedakan menjadi 3 (tiga), yaitu:

1. izin atas dasar kewenangan otonomi;

2. izin atas dasar pelimpahan kewenangan dari pemerintah kepada gubernur atau instansi vertical (dekonsentrasi);

3. izin atas dasar tugas pembantuan.

Izin usaha dalam sistem online single submission (OSS) tidak termasuk dalam ketiga hal diatas. Pada mulanya pembagian kewenangan penerbitan izin terdapat secara jelas dalam lampiran DD dan EE UU 23/2014. Dalam lampiran DD PP 23/2014 telah dibagi bahwa dalam hal pembagian urusan pemerintahan di bidang perdagangan perizinan dan pendaftaran perusahaan dilakukan oleh pemerintah pusat, pemerintah daerah provinsi dan pemeritah daerah kabupaten/kota.

Penerbitan izin usaha dilakukan oleh pemerintah pusat, pemerintah daerah provinsi dan pemerintah daerah kabupaten atau kota sesuai dengan ruang lingkup pembagian kewenangan. Pasca diundangkannya PP 24/2018 tentang OSS kewenangan penerbitan izin seluruhnya ditarik ke pusat melalui lembaga OSS untuk dan atas nama menteri, pimpinan lembaga, gubernur, atau bupati/wali kota kecuali izin berusaha di sektor keuangan, pertambangan, minyak dan gas bumi sebagaimana 
penjelasan Pasal 85 PP 24/2018. Perizinan di sektor keuangan, pertambangan, minyak dan gas bumi memang sudah secara jelas diatur pada Pasal 10 ayat (1) UU 23/2014 sebagai kewenangan absolut yang dimiliki oleh pemerintah pusat.

Unsur keabsahan berikutnya adalah keabsahan substansi. Bahwa dalam hal mengeluarkan suatu ketetatapan (izin) maka substansi dari izin haruslah sesuai dengan hal apa izin tersebut diperuntukkan. Apabila terdapat kecacatan dalam hal substansi maka akan timbul cacat substansi yang berakibat keputusan tersebut batal demi hukum. Substansi izin pasca berlakunya PP 24/2018 dalam rangka percepatan pelayanan berusaha melalui sistem OSS dilakukan reformasi peraturan perizinan berusaha. Izin-izin yang terduhulu memiliki berbagai jenis saat ini ada yang diubah, digabung dan dihapuskan. Reformasi peraturan Perizinan Berusaha sebagaimana dimaksud pada ayat (1) meliputi:

a. pengaturan kembali jenis perizinan, pendaftaran, rekomendasi, persetujuan, penetapan, standar, sertifikasi, atau lisensi;

b. penahapan untuk memperoleh perizinan; dan

c. pemberlakuan Komitmen pemenuhan persyaratan.

Pengaturan kembali jenis perizinan, pendaftaran, rekomendasi, persetujuan, penetapan, standar, sertifikasi, atau lisensi dilakukan melalui pengklasifikasian; penghapusan;penggabungan; perubahannomenklatur; ataupenyesuaian persyaratan. Reformasi jenis perizinan yang menyangkut penghapusan atau penggabungan dilakukan terhadap perizinan yang tidak diperintahkan oleh Undang-Undang atau perizinan tersebut dinilai sudah tidak diperlukan atau tidak efektif apabila dilakukan, contoh dalam Lampiran I Peraturan Menteri Perdagangan Nomor 77 Tahun 2018 tentang Pelayanan Perizinan Berusaha Terintegrasi Secara Elektronik di Bidang Perdagangan Surat Izin Usaha Perdagangan (SIUP), Surat Izin Usaha penjualan Langsung (SIUPL), Surat Izin Usaha Perdagangan Minuman Beralkohol (SIUPMB), Surat IZin Usaha JAsa Survei (SIUJS) Surat Izin Usaha Perusahaan Perantara Perdagangan Properti (SIU-P4), Izin Usaha Toko Swalayan (IUTS), Izin Usaha Pusat Perbelanjaan (IUPP), SIUP Bahan Berbahaya (B2), Surat Izin Usaha Perwakilan Perusahaan Perdagangan Asing, Surat Izin Usaha Perdagangan untuk Jasa Konsultan 
Manajemen Bisnis, Surat Izin Usaha Perdagangan untuk jasa Penyewaan Mesin, Surat Izin Usaha Pengundangan untuk Jasa Pengundangan termasuk cold storage digabung dengan catatan menjadi Surat Izin Usaha Perdagangan (SIUP) dengan catatan tiap bidang usaha memiliki persyaratan izin yang berbeda.

Perizinan Berusaha yang berdasarkan Peraturan Pemerintah ini dilakukan penghapusan, penggabungan, atau perubahan nomenklatur Perizinan Berusaha namun sebelumnya telah ditetapkan sebagai penerimaan negara bukan pajak, pajak daerah atau retribusi daerah, Pelaku Usaha tetap melakukan pembayaran atas penerimaan negara bukan pajak, pajak daerah, atau retribusi daerah berdasarkan ketentuan sebelum berlakunya Peraturan Pemerintah ini.

Izin berusaha yang menjadi lingkup OSS sebagaimana ketentuan Pasal 85 PP 24/2018 terdiri atas perizinan berusaha pada sektor ketenagalistrikan; sektor pertanian; sektor lingkungan hidup dan kehutanan; sektor pekerjaan umum dan perumahan rakyat; sektor kelautan dan perikanan; sektor kesehatan; sektor obat dan makanan; sektor perindustrian; sektor perdagangan; sektor perhubungan; sektor komunikasi dan informatika; sektor keuangan; sektor pariwisata; sektor pendidikan dan kebudayaan; sektor pendidikan tinggi; sektor agama dan keagamaan; sektor ketenagakerjaan; sektor kepolisian; sektor perkoperasian dan usaha mikro, kecil, menengah; dan sektor ketenaganukliran.

Unsur keabsahan berikutnya yaitu keabsahan prosedur. Pada umunya permohonan izin harus menempuh prosedur tertentu yang ditentukan oleh pemerintah selaku pemberi izin. Selain harus menempuh prosedur tertentu, pemohon izin juga harus memenuhi persyaratan-persyaratan tertentu yang ditentukan secara sepihak oleh pemerintah atau pemberi izin. ${ }^{19}$ Meskipun ditentukan secara sepihak namun pemerintah tidak boleh membuat atau menentukan prosedur dan persyaratan menurut kehendaknya sendiri secara arbitrer (sewenang-wenang) tetapi harus sejalan dengan peraturan perundang-undangan yang menjadi dasar perizinan tersebut. ${ }^{20}$ Prosedur dalam pengajuan perizinan berusaha saat ini tengah dikelola

\footnotetext{
${ }^{19}$ Adrian Sutedi, Op.Cit., [185].

${ }^{20}$ ibid.
} 
oleh lembaga OSS sebagaimana ketentuan PP 24/2018. Para pemohon izin dapat mengakses laman url: http://oss.go.id.

Izin merupakan salah satu bentuk keputusan pemerintah, berdasarkan Pasal 1 angka 19 UU 30/2014 izin adalah keputusan pejabat pemerintahan yang berwenang sebagai wujud persetujuan atas permohonan warga masyarakat sesuai dengan ketentuan peraturan perundang-undangan. Izin sebagai salah satu bentuk keputusan pemerintah terbit melalui serangkaian proses yang dimulai dari tahapan permohonan sampai dengan tahapan pemberian keputusan. Secara teoritis Mr. N.M. Spelt mengemukakan asas-asas prosedur diantaranya adalah:

1. Permohonan;

2. Acara persiapan dan peran serta;

3. Pemberian keputusan;

4. Susunan keputusan;

5. Pengumuman keputusan.

Langkah-langkah untuk mendapatkan izin usaha berdasarkan PP 24/2018 diantaranya:

a. Menyatakan komitmen penyelesaian izin prasyaratnya, yaitu Izin Lokasi, Izin Lingkungan, IMB, atau persyaratan izin usaha lainnya (jika dipersyaratkan).

b. OSS menerbitkan Izin Usaha.

c. Menerima notifikasi dari OSS bahwa Izin Usaha telah diaktivasi setelah pelaku usaha memenuhi komitmen Izin Lokasi, Izin Lingkungan/SPPL, Izin Mendirikan Bangunan Gedung, Sertifikat Laik Fungsi, persyaratan izin usaha lainnya telah dipenuhi dan telah melakukan pembayaran (jika dipersyaratkan).

Philipus M. Hadjon mengemukakan bahwa suatu prosedur yang baik hendaknya memenuhi 3 (tiga) landasan utama hukum administrasi, yaitu:

1. asas negara hukum dalam prosedur;

2. asas demokrasi dalam prosedur;

3. asas instrumental. ${ }^{21}$

${ }^{21}$ Philipus M. Hadjon, Op. Cit.[268]. 
Pada proses perizinan membutuhkan adanya pengetahuan tidak hanya sebatas pada aspek legal tetapi juga mempertimbangkan dampak yang akan ditimbulkan dari izin tersebut baik dalam jangka pendek ataupun jangka panjang. Itulah sebabnya dalam sistem Online Single Submission (OSS) diterapkan mekanisme izin bersyarat. Mengutip pandangan Soehino dalam bukunya yang berjudul AsasAsas Hukum Tata Pemerintahan, syarat-syarat dalm izin itu bersifat konstitutif dan kondisional. ${ }^{22}$ Bersifat konstitutif apabila suatu perbuatan atau tingkah laku tertentu yang harus (terlebih dahulu) dipenuhi, artinya dalam hal pemberian izin itu ditentukan suatu perbuatan bersifat konkret apabila tidak dipenuhi maka lahirlah sanksi. Bersifat kondisional apabila penilaian tersebut baru ada dan dapat dilihat serta dapat dinilai setelah perbuatan yang disyaratkan terjadi.

Berdasarkan ketentuan Pasal 64 ayat (1) UU 30/2014 keputusan hanya dapat dilakukan pencabutan apabila terdapat cacat: wewenang, prosedur, dan/ atau substansi. Dalam hal keputusan dicabut, harus diterbitkan keputusan yang baru dengan mencantumkan dasar pencabutannya serta tetap memperhatikan AUPB. Adapun pejabat yang berwenang mencabut keputusan tersebut adalah pejabat pemerintahan yang menetapkan keputusan, atasan pejabat yang mentapkan keputusan atau atas perintah pengadilan. Berdasarkan asas ius contrarius actus yang artinya badan atau pejabat tata usaha negara yang menerbitkan keputusan tata usaha negara dengan sendirinya berwenang membatalkan, sehingga dalam hal pencabutan izin harus dilakukan oleh pejabat yang berwenang. Hal tersebut yang juga kemudian menjadi dasar bahwa apabila gagal dilakukan pemenuhan komitmen maka lembaga OSS berwenang membatalkan izin usaha yang sudah dikeluarkan. Hal tersebut telah diatur secara eksplisit dalam Pasal 40 PP 24/2018. ${ }^{23}$

Tidak dipenuhinya unsur-unsur keabsahan izin sebagai suatu tindakan pemerintahan (dengan adanya cacat kewenangan, substansi dan prosedur) menyebabkan ketidakpastian hukum dalam penerbitan izin melalui sistem online single submission (OSS).

\footnotetext{
${ }^{22}$ Soehino Mertokusumo, Asas-Asas Hukum Tata Pemerintahan (Liberty 1984).[97].

${ }^{23}$ Riduan Syahrani, Rangkuman Intisari Ilmu Hukum (Citra Aditya Bakti 1999).[23].
} 


\section{Problematika Pelaksanaan Penerbitan Izin Usaha melalui Sistem Online Single Submission (OSS)}

Pasca berlakunya Sistem Online Single Submission (OSS) dalam rangka menunjang ease of doing business (EODB) ternyata berkorelasi secara signifikan dalam menaikkan peringkat kemudahan perizinan di Indonesia. Berdasarkan data yang dilansir Bank Dunia dengan berlakunya OSS indicator starting a business naik 10 peringkat dari 144 menjadi 134. Sekalipun peringkat EODB Indonesia dalam laporan Doing Business 2019 turun dari peringkat 72 menjadi peringkat 73, namun indeks EODB Indonesia naik 1,42 menjadi 67,96 dibandingkan tahun sebelumnya. ${ }^{24}$

Indicator starting a business dapat terlihat dikemas berdasarkan ketentuan Pasal 84 ayat (4) PP 24/2018 melalui tahapan untuk memperoleh perizinan berusaha yang terdiri atas:

a. pendaftaran;

b. pemberian izin usaha; dan

c. pemberian izin komersial atau operasional.

Pemberian izin dimuka menunjukkan adanya kemudahan dalam pelaksanaan starting a business yang selama ini Indoensia sempat tertinggal dari Singapura, Malaysia, bahkan Vietnam. ${ }^{25}$ Adapun dalam pemberian izin komersial atau operasional berdasarkan ketentuan ayat (5) pasal tersebut haruslah dilakukan proses pemenuhan komitmen. Bahwa Pemberlakuan Komitmen pemenuhan persyaratan dilakukan untuk melakukan usaha dan/atau kegiatan sesuai dengan izin usaha atau izin komersial atau operasional yang telah diterbitkan. Apabila pemohon izin gagal dalam melakukan pemenuhan komitmen maka menimbulkan ketidakpastian hukum bagi pemohon.

Izin usaha yang terbit melalui sistem online single submission (OSS) tidak hanya mengalami cacat substansi (tidak memenuhi unsur keabsahan sebagai tindakan pemerintahan) sebagaimana telah dijelaskan pada sub bab sebelumnya. Bahwa berdasarkan keabsahan yang pertama terkait wewenang sumber kewenangan

\footnotetext{
${ }^{24}$ Prima Wirayani, Loc. Cit.

${ }^{25}$ Agung Pambudhy, Loc. Cit.
} 
yang diperoleh oleh lembaga OSS berasal dari peraturan pemeritah hal tersebut telah melanggar komponen wewenang khususnya dasar hukum. Peraturan Pemerintah sebagai legitimasi OSS tidak dibuat berdasarkan persetujuan dari wakil rakyat. Wewenang lembaga OSS yang didapatkan melalui legitimasi Peraturan Pemerintah tidaklah sah karena melanggar komponen dasar hukum wewenang. Tidak sahnya wewenang dalam suatu izin berakibat izin tersebut batal demi hukum. Pada saat ini pemerintah daerah mematuhi mekanisme OSS atas dasar prinsip negara kesatuan namun kondisi di lapangan memperlihatkan kelemahan PP 24/2018 yang bertentangan dengan beberapa aturan termasuk aturan dalam UU 23/2014. Tidak sahnya wewenang dalam suatu izin berakibat izin tersebut batal demi hukum. Dilema sah atau tidaknya keputusan yang diterbitkan oleh lembaga OSS melalui sistem OSS menyebabkan ketidakpastian hukum bagi pemohon izin.

Izin usaha yang terbit melalui Sistem Online Single Submission (OSS) dalam implementasinya juga menimbulkan legitimate expectation. Pada prinsipnya kebijakan OSS memang dimaksudkan untuk menunjang iklim investasi di Indonesia yaitu dalam rangka menaikkan poin EODB, namun ternyata kebijakan tersebut mengakibatkan ketidakpastian hukum pemegang izin usaha yang membutuhkan pemenuhan komitmen. Konsep pemenuhan komitmen yang dilakukan pasca diterbitkannya izin usaha menjadikan izin usaha terkesan mandul karena tidak dapat secara langsung berfungsi sebelum dikeluarkannya izin operasional. Dengan kata lain izin usaha tidak bersifat final karena membutuhkan izin lebih lanjut. Hanya ada beberapa izin usaha yang bersifat final yaitu izin usaha yang skaligus izin operasional tanpa pemenuhan komitmen seperti izin usaha perdagangan (siup). Hal tersebut menunjukkan adanya praktik legitimate expectation yang dilakukan oleh pemerintah Indonesia kepada pemegang izin usaha melalui sistem OSS.

Dalam konsep yuridis, kepastian hukum mengandung dua komponen utama yaitu aturan hukum yang konsisten dan penerapan hukum secara konsisten. Apabila kita amati izin usaha dalam sistem OSS berasal dari aturan hukum yang konsisten yakni mendapatkan legitimasi dari PP 24/2018, namun menjadi pertanyaan apakah 
izin usaha merupakan penerapan hukum yang konsisten atau tidak. Dengan sistem yang mendapatkan izin terlebih dahulu baru kemudian melengkapi komitmen maka terdapat bentuk tidak konsisten penerapan hukum karena apabila pemegang izin usaha tidak kunjung memenuhi komitmen sebagaimana batas waktu yang telah ditentukan maka izin usaha dapat dibatalkan oleh lembaga OSS sebagaimana ketentuan Pasal 40 PP 24/2018. Merujuk pada pendapat N.M.Spelt dalam bukunya berjudul Pengantar Hukum Perizinan, bahwa dengan menetapkan syarat-syarat, akibat-akibat hukum tertentu digantungkan pada timbulnya suatu peristiwa di kemudian hari yang belum pasti. Ketidakjelasan tentang saat di mana suatu syarat dipenuhi, dapat merupakan sebab terjadinya ketidakpastian hukum. ${ }^{26}$ Maka dalam hal ini muncullah legitimate expectation yang diberikan pemerintah kepada pemohon izin berupa izin usaha yang belum tentu berlaku efektif.

The principle of good faith menentukan bahwa pejabat yang berwenang harus menghargai harapan (legitimate expectations) yang telah diberikan kepada para pihak yang terlibat. Uni Eropa menggunakan prinsip umum pemerintahan sebagai general principle of community, seperti disebut artikel 220 EC. The general principles dikembangkan melalui case law oleh mahkamah internasional Uni Eropa (European Court of Justice), yang diambil atau disemangatai oleh hukum negara-negara anggota, seperti ditegaskan dalam Art. 288 EC: "even explicitly prescribes that a community principle must be in accordance with general principle common to the law of the member state". ${ }^{27}$

Konsep harapan yang sah (legitimate expectation) ialah konsep yang relatif baru yang telah dibuat oleh pengadilan untuk peninjauan tindakan administratif. Konsep ini dikenalkan oleh Lord Denning di Schimdt V bahwa ia mengakui sebagai orbiter hak kepentingan atau harapan yang sah dari seorang individu terhadap suatu administrasi tindakan sehubungan dengan hak untuk didengar. Harapan yang sah muncul sebagai hasil dari janji, representasi, praktik, kebijakan yang dibuat, diadopsi atau diumumkan atas nama pemerintah atau otoritas publik.

\footnotetext{
${ }^{26}$ Mr Spelt et al, Op.Cit.[14].

27 Tatiek Sri Djatmiati, Perizinan Sebagai Instrumen Yuridis dalam Pelayanan Publik, (Pidato Pengukuhan Jabatan Guru Besar dalam Ilmu Hukum pada Fakultas Hukum Universitas Airlangga 2007).[12-13].
} 
Penerapan prinsip umum oleh ECJ yang disemangati hukum negara-negara anggota tidak terlalu aneh, pertimbangannya karena para hakim di ECJ murni diambil dari negara-negara anggota sehingga prinsip umum pemerintahan dinegara anggota yang meliputi: the principle of equality, the principle of proportionality, the right of defence, the principle of legitimate expectations, the principle of legal certainly and the duty to state reasons. ${ }^{28}$

Selain beberapa problematika diatas juga terdapat problematika pertentangan antara peraturan perundang-undangan yang ada terkait pelaksanaan sistem OSS. Beberapa aturan yang bertentangan dengan PP 24/2018 diantaranya ialah :

- pembagian urusan pemerintahan sudah diatur secara rigid dalam UU 23/2014 beserta lampirannya, penerbitan izin sebagai urusan konkuren merupakan kewenangan yang tidak hanya dimiliki oleh pemerintah pusat tetapi juga dimiliki oleh pemerintah provinsi dan pemerintah kabupaten/kota, kehadiran PP 24/2018 seolah-olah mengambil alih kewenangan daerah untuk dilaksanakan oleh Lembaga OSS;

- dalam hal penggunaan prinsip mandat dalam UU 30/2014 secara jelas menyebutkan bahwa kewenangan berasal dari atasan kepada bawahan, namun dalam PP 24/2018 kewenangan berasal dari pemerintah daerah padahal tidak terdapat hubungan hirarkis antara pemerintah daerah dengan Lembaga OSS;

- dalam hal penyelenggaraan perizinan penanaman modal berdasarkan UndangUndang Nomor 25 Tahun 2007 tentang Penanaman Modal dilaksanakan oleh PTSP namun dalam PP 24/2018 dilaksanakan oleh Lembaga OSS.

Berdasarkan asas lex superiori derogat legi inferiori maka kedudukan hukum yang tinggi mengalahkan hukum yang lebih rendah. Dalam hierarkhi peraturan perundang-undangan posisi Peraturan Pemerintah berada dibawah Undang-Undang sebagaimana ketentuan Pasal 7 ayat (1) Undang-Undang Nomor 12 Tahun 2011 tentang Pembentukan Peraturan Perundang-undangan sehingga berdasarkan asas lex superiori derogat legi inferiori hukum yang berlaku adalah sebagaimana ada 
pada undang-undang. Mekanisme yang dapat diajukan ialah mekanisme uji materiil kepada Mahkamah Agung atas PP 24/2018 terhadap UU 23/2014, UU 30/2014, dan/atau UU 25/2007.

\section{Kesimpulan}

Pada prinsipnya kebijakan OSS memang dimaksudkan untuk menunjang iklim investasi di Indonesia, namun kebijakan tersebut juga mengakibatkan munculnya problematika hukum dalam penerapannya. Problematika itu diantaranya terdapat cacat wewenang, substansi dan prosedur dalam keabsahan izin usaha yang diterbitkan melalui sistem OSS; ketidakpastian hukum atas izin usaha yang belum final sehingga mengakibatkan adanya praktik legitimate expectation yang dilakukan oleh pemerintah kepada pemegang izin usaha; serta adanya pertentangan norma antara PP 24/2018 yang mengatur tentang Sistem OSS dengan UU 23/2014, UU 30/2014 dan UU 25/2007.

Kemudahan sistem perizinan di Indonesia pasca berlakunya OSS memang mendapatkan respon yang positif dari para investor dalam memulai investasi di Indonesia. Namun terhadap problematika yang terjadi memerlukan adanya uji materiil terhadap PP 24/2018.

\section{Daftar Bacaan}

\section{Buku}

Adrian Sutedi, Hukum Perizinan Dalam Sektor Pelayanan Publik (Sinar Grafika 2017).

H. A. Masyhur Effendi, Hak Asasi Manusia Dalam Hukum Nasional dan Internasional (Ghalia Indonesia 1993).

I Made Pasek Diantha, Metodologi Penelitian Hukum Normatif (Prenada Media Group 2016).

Kementerian Koordinator Bidang Perekonomian Republik Indonesia, Online Single Submission, (Panduan Penggunaan Registrasi OSS version 1.00 Kementerian Koordinator Bidang Perekonomian Republik Indonesia 2018. 
Philipus M. Hadjon, et.al, Pengantar Hukum Administrasi Indonesia (Gadjah Mada University Press 2002).

Philipus M. Hadjon. ed, Pengantar Hukum Perizinan (Yuridika 1993).

Riduan Syahrani, Rangkuman Intisari Ilmu Hukum (Citra Aditya Bakti 1999).

Soehino Mertokusumo, Asas-Asas Hukum Tata Pemerintahan (Liberty 1984).

Soerjono Soekanto dan Sri Mamudji, Penelitian Hukum Normatif (Rajagrafindo Persada 1985).

Tatiek Sri Djatmiati et.al, Buku Ajar Hukum Perizinan (Yuridika 2012).

Tatiek Sri Djatmiati, Perizinan Sebagai Instrumen Yuridis dalam Pelayanan Publik, (Pidato Pengukuhan Jabatan Guru Besar dalam Ilmu Hukum pada Fakultas Hukum Universitas Airlangga 2007).

\section{Jurnal}

Erick S. Holle, 'Pelayanan Publik Melalui Electronic Government : Upaya meminimalisir Praktek Maladministrasi dalam Meningkatkan Public Service', (2011), 17 Jurnal Sasi.

Philipus M. Hadjon, ‘Tentang Wewenang' 1990, Yuridika 1990.

\section{Laman}

Agung Pambudhy, 'Kemudahan Usaha RI Kalah dari Vietnam Hingga Singapura' (m.detik.com, 2019) <https://m.detik.com/finance/berita-ekonomibisnis/d-4283004/kemudahan-usaha-ri-kalah-dari-vietnam-hinggasingapura $>$ accessed 21 Januari 2019.

Arya Aditya, 'Sistem Perizinan Online Tunggal, Jokowi : Kita Paksa'(cnbcindonesia. com, 2018) <https://www.cnbcindonesia.com/news/20180418171510-411538/sistem-perizinan-online-tunggal-jokowi-kita-paksa $>$ accessed 18 September 2018.

Prima Wirayani, 'Ease od Doing Business RI Turun, Ini Penjelasan Bank Dunia', (cnbcindonesia.com, 2018) <http://www.cnbcindonesia,com/ news/20181031201049-4-40020/ease-of-doing-business-ri-turun-inipenjelasan-bank-dunia> accessed 20 April 2018. 